\title{
MAPPING MINORITIES’ VULNERABILITY TO HATE SPEECH AND DENATIONALISATION WITH A FOCUS ON EAST AND SOUTHEAST ASIA
}

\author{
KATALIN BERÉNYI*
}

This paper explores whether minority groups are more vulnerable to hate speech, human rights violations, denationalisation and mass atrocities in light of the deliberate lack of state protection through the lens of recent incidents in East and Southeast Asia. The paper also examines the role of social media giant Facebook in spreading hate speech online and whether it may have had any liabilities in relation to the hateful posts that were spread online against the Rohingyas in Myanmar and, more recently, against the Muslim minorities living in the State of Assam in India. The paper concludes by (1) advising policy-makers to adopt and implement strong anti-hate speech laws, clearly criminalising both online and offline hate speech on the national level, as well as to (2) refrain from denationalising minority groups leaving them stateless or at the risk of statelessness and thus avoid instrumentalising nationality for political gains.

\section{TABLE OF CONTENTS}

I Introduction 5

II Statelessness: A Minority Issue Intertwined with Hate Speech? ............................. 9

III Ethnic discrimination lies at the core of statelessness in Asia ................................ 11

IV Ethnic Koreans Subject to Mass Denationalisation and Hate Speech in Japan ...... 12

V Hate Speech against the Stateless Rohingya Facilitated by Facebook: Lessons Learned?

VI Hate Speech against Minorities in the State of Assam, India: Lessons Ignored..... 19

VII Conclusion 22

\section{INTRODUCTION}

My community too fell victim to social media, as Facebook allowed the Burmese nationalists to spread their toxic and violent hate against us until it was too late for too many. My message to the social media platforms is 'Stop allowing malicious actors to weaponize tools of connection into tools of hate. Learn from your mistakes. Act now.' 1

— Tun Khun, President of Burmese Rohingya Organisation UK June, 2019

* PhD. Statelessness Consultant, United Nations High Commissioner for Refugees ('UNHCR'). The views expressed are solely those of the author and are not attributable to UNHCR.

1 Quoted in Megaphone for Hate: Disinformation and Hate Speech on Facebook during Assam's Citizenship Count (Report, AVAAZ October 2019) 3 $<$ https://avaazpress.s3.amazonaws.com/FINAL-

Facebook\%20in\%20Assam_Megaphone \%20for\%20hate $\% 20-\% 20$ Compressed $\% 20(1)$.pdf $>$ ('Megaphone for Hate'). 
While statelessness may have different causes, ${ }^{2}$ the consequences for the individual often manifest in the same difficult human experience: rejection, exclusion, marginalisation and the feeling of not belonging anywhere. ${ }^{3}$ Nationality is important in that it creates a legal bond between state and individual. It allows for the enjoyment of basic rights, including the rights to education, work, health care, consular protection, as well as the right to reside in and return to a country. Stateless people are often viewed as 'aliens' residing illegally in their country of origin or habitual residence, and thus are often subject to prolonged immigration detention, as well as deportation to third countries. In the deliberate lack of state protection, individuals belonging to minorities ${ }^{4}$ - either already stateless or at (heightened) risk of becoming stateless - are extremely vulnerable not only to destitution, human trafficking and forced labour, but also to systematic and widespread hate speech, ${ }^{5}$ arbitrary actions committed by both state actors and civilians, forced labour, enforced disappearances and extrajudicial killings that

2 Inter alia state dissolution/succession, ill-defined/discriminatory nationality laws (as direct instances of ethnic, religious or gender-based discrimination), birth to a stateless parent, lack of birth registration or inability to satisfy certain technical requirements for the acquisition of nationality. See Handbook on Statelessness in the OSCE Area: International Standards and Good Practices (Report, OSCE and UNHCR 28 February 2017) $<$ https://www.osce.org/files/f/documents/5/1/302201.pdf $>$.

3 See 'This Is Our Home': Stateless Minorities and their Search for Citizenship (Report, UNHCR, 3 November 2017) <https://www.unhcr.org/ibelong/wpcontent/uploads/UNHCR_EN2_2017IBELONG_Report_ePub.pdf $>$ ('This Is Our Home'). See also Stateless in Europe: Ordinary People in Extraordinary Circumstances (Report, UNHCR March 2018).

4 While there is no internationally agreed definition as to which groups constitute minorities, the United Nations has provisionally defined minorities as based on national or ethnic, cultural, religious and linguistic identity, and has provided that states should protect their existence. See Declaration on the Rights of Persons Belonging to National or Ethnic, Religious and Linguistic Minorities, GA Res 47/135, UN Doc A/RES/47/135 (3 February 1993) annex art 1. Another important element is that minorities are in non-dominant position in any given society. See Francesco Capotorti, Study on the Rights of Persons Belonging to Ethnic, Religious and Linguistic Minorities, UN Doc E/CN.4/Sub.2/384/Rev.1 (1979) 96 [568].

5 Although there is no established definition of hate speech, for the purpose of this study, hate speech is defined as any verbal or written manifestation of discrimination, hostility or hatred on the basis of race, ethnicity, language, religion, nationality, origin, gender, and other identities, instigation thereto, and instigation of violence. Instead of prohibiting hate speech as such, international law forbids the incitement to discrimination, hostility and violence. Incitement constitutes a dangerous form of hateful speech, because it explicitly and deliberately aims at generating discrimination, hostility and violence against an individual or a group of individuals which may lead to atrocity crimes. See United Nations Strategy and Plan of Action on Hate Speech (Strategy Document, 18 June 2019) ('UN Strategy and Plan of Action on Hate Speech'). Furthermore, claims about a group's inferiority, calls for violence against an individual or an entire group because of their fixed identity characteristics and the use of racist, homophobic, or ethic slurs all constitute hate speech. See Caitlin Carlson, 'Censoring Hate Speech in Social Media Content: Understanding the User's Perspective' (2017) 17(1) Communication Law Review 24. 
may amount to mass atrocity crimes. ${ }^{6}$ These are each illustrated by recent incidents in relation to ethnic Koreans in Japan, the Rohingyas in Myanmar, and the Bengali and other mostly Muslim minorities who are currently at high risk of statelessness in the State of Assam, India.

This article is based on literature concerning hate speech targeting minorities, ${ }^{7}$ online hate speech ${ }^{8}$ and sporadic literature addressing online hate speech targeting minority groups in the statelessness context, mainly reports exploring hate speech spread online against the Rohingyas ${ }^{9}$ and Muslim minorities in Assam, India. ${ }^{10}$ This study aims to contribute to the existing body of literature and suggest findings on the role and responsibility of Facebook in spreading hate speech targeting minorities who are either already stateless or are at risk of statelessness. It also explores how hate speech may contribute to the denationalisation of a minority group. These correlations are portrayed below through case studies of denationalisation. In particular, in conjunction with secondary sources, this article examines the cases of ethnic Koreans in Japan, Muslim minorities living in Myanmar and in the State of Assam, India.

6 Genocide, war crimes and crimes against humanity are defined as mass atrocity crimes in international legal documents, see especially Convention on the Prevention and Punishment of the Crime of Genocide, opened for signature 9 December 1948, 78 UNTS 277 (entered into force 12 January 1951); Geneva Convention for the Amelioration of the Condition of the Wounded and Sick in Armed Forces in the Field, opened for signature 12 August 1949, 75 UNTS 31 (entered into force 21 October 1950); Geneva Convention for the Amelioration of the Condition of Wounded, Sick and Shipwrecked Members of the Armed Forces at Sea, opened for signature 12 August 1949, 75 UNTS 85 (entered into force 21 October 1950); Geneva Convention Relative to the Treatment of Prisoners of War, opened for signature 12 August 1949, 75 UNTS 135 (entered into force 21 October 1950); Geneva Convention Relative to the Protection of Civilian Persons in Time of War, opened for signature 12 August 1949, 75 UNTS 287 (entered into force 21 October 1950); Rome Statute of the International Criminal Court, opened for signature 17 July 1998, 2187 UNTS 3 (entered into force 1 July 2002). In addition to these crimes, ethnic cleansing is seen as a fourth mass atrocity crime despite the lack of legal recognition as an independent crime under international law. The term 'ethnic cleansing' was used in the context of the 1990's conflict in the former Yugoslavia and has been applied in United Nations Security Council and General Assembly resolutions. See Defining the Four Mass Atrocity Crimes (Report, Global Centre for the Responsibility to Protect 15 August 2018) <https://www.globalr2p.org/publications/defining-the-four-massatrocity-crimes $/>$.

7 See generally Barbara Perry, In the Name of Hate: Understanding Hate Crimes (Routledge 2001); Shannon Fyfe, 'Tracking Hate Speech Acts as Incitement to Genocide in International Criminal Law' (2017) 30(2) Leiden Journal of International Law 523; Ilja Richard Pavone, 'Italian Experiences in Combating Hate Crimes and Hate Speech in Light of Recent Violence by and against Roma' (2010) 51(3) Acta Juridica Hungarica 187; Rob White and Santina Perrone, 'Racism, Ethnicity and Hate Crime' (2001) 9(2) Communal/Plural 161; Jeannine Bell, 'Restraining the Heartless: Racist Speech and Minority Rights' (2009) 84(3) Indiana Law Journal 963; Susan Benesch, 'Defining and Diminishing Hate Speech' [2014] State of the World's Minorities and Indigenous Peoples 18.

8 See generally Danielle Keats Citron, Hate Crimes in Cyberspace (Harvard University Press 2014); James Banks, Regulating Hate Speech Online (2010) 24(3) International Review of Law, Computers \& Technology 233; Pete Burnap and Matthiew L Williams, 'Cyber Hate Speech on Twitter: An Application of Machine Classification and Statistical Modelling for Policy and Decision Making' (2015) 7(2) Policy and Internet 223; Kevin Durrheim, Ross Greener and Kevin A Whitehead, 'Race Trouble: Attending to Race and Racism in Online Interaction' 54(1) British Journal of Social Psychology 84; Abraham H Foxman, Christopher Wolf, Viral hate: Containing Its Spread on the Internet (Palgrave Macmillan 2013).

9 Steve Stecklow, Hatebook: Inside Facebook's Myanmar Operation: Why Facebook is Losing the War on Hate Speech in Myanmar (Report, Reuters 15 August 2018) $<$ https://www.reuters.com/investigates/special-report/myanmar-facebook-hate/> ('Hatebook').

10 Megaphone for Hate (n 1). 
Hate speech is disseminated by several means, including hateful street graffiti, hate-fuelled protests where symbols conveying hostile messages towards a group are worn, and sharing hateful speech on the internet. In recent years the instrumentalisation of the internet, and especially social media in this regard, have been apparent. Facebook is the most widely used social network worldwide. ${ }^{11}$ With 2.3 billion active users, it has changed the way we access information whether it be the way we interact with one another, the news or mobilisation for political change. ${ }^{12}$ This has led to a social recession away from state-owned media outlets that may be inclined to convey politically biased information, to the more public or crowd-sourced information that Facebook can provide. ${ }^{13}$ Facebook provides users the opportunity to express their opinions freely and connect with like-minded users through dedicated groups, enjoying a sense of togetherness and engaging in exchanges on any issue of public interest. By sharing media content and providing a platform for interactive discussion, Facebook implicitly contributes to shaping public discourse on issues of public interest and, thus, promotes the mobilisation of masses. While Facebook is often used for positive and inspiring mobilising purposes, it has also been widely instrumentalised in the spreading of hate speech.

Some Facebook users may be more inclined to express their frustration and hatred against certain social groups online rather than in the physical world. The problem is that the online space may provide hate-fuelled speakers a platform to encourage and incite each another in a harmful way, towards becoming offline bullies. Online platforms such as YouTube, Facebook and Twitter have indirectly contributed to an increasing wave of harmful videos, hate-oriented groups and racist images encouraging violence against helpless minorities, ${ }^{14}$ despite joints efforts to counter this phenomenon. ${ }^{15}$ While users may assume that their harmful online activities and hateful messages do not amount to physical attacks against their victims in the street, a recent study revealed that there is a consistent link between 'hate tweets' targeting religious and ethnic minorities and physical violence towards them, suggesting that an increase in hate speech on social media does lead to increased crimes against minorities in the physical world. ${ }^{16}$ At the peak of the Rohingya crisis - 2017-18 — there was much discussion of Facebook's liability in being used as a platform to fuel online hate against the Rohingyas and incite physical violence against them. Before looking into Facebook's role in spreading online hate during the very recent incidents in Myanmar and India, the article will turn to Japan in the 2000s. There, the internet already played a key role in the incitement of hate speech against an ethnic

11 According to Statista as of May 2020. See Statista (Web Page, May 2020) $<$ https://www.statista.com/statistics/272014/global-social-networks-ranked-by-number-ofusers/ $>$.

12 Esteban Ortiz-Ospina, The Rise of Social Media (Report, Our World in Data 18 September $2019)<$ https://ourworldindata.org/rise-of-social-media $>$.

13 Mike Friedrichsen and Yahya Kamalipour (eds), Digital Transformation in Journalism and News Media. Media Management, Media Convergence and Globalization (Springer International 2017) 221.

14 Benesch (n 7) 19.

15 In 2016, Facebook, Twitter, YouTube and Microsoft signed the European Union Code of Conduct on Countering Illegal Hate Speech Online, making a commitment to address hate speech on their platforms.

16 See Matthew L Williams et al, 'Hate in the Machine: Anti-Black and Anti-Muslim Social Media Posts as Predictors of Offline Racially and Religiously Aggravated Crime' (2020) 60(1) The British Journal of Criminology 93. 
minority group in Asia affected by statelessness comparable to the situations in Myanmar and India.

\section{Statelessness: A Minority Issue InTERTwined with Hate Speech?}

Statelessness constitutes a violation of the basic right to a nationality and must be viewed as a human rights issue that disproportionately affects minorities around the world. According to the United Nations High Commissioner for Refugees ('UNHCR') today more than 75 per cent of the world's known stateless populations belong to minority groups. ${ }^{17}$ Considering the lack of awareness of the root causes, underlying and indirect reasons for statelessness in many countries, the connection between minorities and statelessness may not have been apparent enough for public discourse and, thus, has only been sporadically discussed in general debates. Despite UN special rapporteurs reflecting on the nexus between minorities facing discrimination, exclusion, citizenship denial, ${ }^{18}$ and the issue of racial discrimination in the context of laws, policies and practices ${ }^{19}$ on some occasions, the nexus between statelessness and minorities remained a dormant issue for quite some time. Contemporary discourse has, however, gradually awoken policy discussions in the context of fundamental rights, minority rights and national identity.

Consequently, the UN Forum on Minority Issues chose to reflect on the topic 'Statelessness: A Minority Issue' during its $11^{\text {th }}$ session on 29-30 November in 2018, aimed at addressing the interconnection between the promotion and protection of the human rights of persons belonging to national or ethnic, religious and linguistic minorities and statelessness' ${ }^{20}$ The forum sought to consider more closely how human rights violations in minority contexts can be addressed to avoid the denial or deprivation of nationality resulting in statelessness for millions of minorities. The massive overrepresentation of minorities in stateless populations suggests that the denial or deprivation of citizenship may neither be entirely arbitrary nor accidental, but rather the result of deliberate policies and practices that render many of those who belong to minorities stateless and therefore particularly vulnerable in many societies. ${ }^{21}$

The selective approach lying behind denationalisation - deprivation of nationality through state action - may be driven by distinct political motives to

17 This Is Our Home (n 2) $1 \mathrm{n}$ 1: This percentage is based on statistics for stateless populations included in UNHCR's 2016 Global Trends Report that are known to belong to an ethnic, religious or linguistic minority, not including 'minority groups that compose a proportion of a known stateless population in a country but do not form the majority of that population'. See also Global Trends: Forced Displacement in 2016 (Report, 2016) $<$ https://reliefweb.int/sites/reliefweb.int/files/resources/5943e8a34.pdf $>$.

18 See, eg, Gay McDougall, Promotion and Protection of All Human Rights, Civil, Political, Economic, Social and Cultural Rights Including the Right to Development, UN Doc A/HRC/7/23 (28 February 2008).

19 See, eg, Tendayi Achiume, Report of the UN Special Rapporteur on Contemporary Forms of Racism, Racial Discrimination, Xenophobia and Related Intolerance, UN Doc A/HRC/38/52 (25 April 2018).

20 'UN Forum on Minority Issues', UNHCR (Web Page) $<$ https://www.unhcr.org/ibelong/event/un-forum-on-minority-issues/>.

21 Fernand de Varennes, Effective Promotion of the Declaration on the Rights of Persons Belonging to National or Ethnic, Religious and Linguistic Minorities, UN Doc A/73/205 (20 July 2018) 6-7 [21]. 
create or maintain a desired status quo within society. ${ }^{22}$ To achieve it, some states arbitrarily deprive individuals belonging to 'unwanted' minority groups from bearing the nationality, regardless of their long-term residence or even birth in the country, and deny them the rights inherent in having a nationality. ${ }^{23}$ Denationalisation based on racial, ethnic, religious and related grounds has been resorted to by states as a drastic form of penalty or punishment for political or historical reasons aimed at excluding national minorities. ${ }^{24}$

History reveals how states may single out ethnic or religious groups residing in their territory considering them 'disfavoured', systematically discriminate against them and later exclude them from the body of citizens, often regarding them illegitimate members of society who are illegally residing in the territory of the state - rendering them stateless. ${ }^{25}$ In their pursuit of societal bias, states can systematically draft and adopt laws and policies that strip minorities of nationality, taking away their basic rights and leaving them seemingly without the popular representation in public life that would be crucial towards the recognition of minorities and their issues, ${ }^{26}$ as well as their ability to represent their interests.

Instead of addressing public representation of minority groups by bringing them to the negotiation table (serving the long-term interests of the state by promoting an integrated society), these ruling regimes incite state sponsored hate speech against the given minority group at hand. ${ }^{27}$ Law enforcement actors and the (dominant) majority population can feel legitimised to disrespect members of these minority groups, potentially leading to severe abuses against minority groups, and convincing them there will be no repercussions for their actions. ${ }^{28}$ Consequently, hate speech can be very harmful in itself and especially in cases where it comes from the hierarchy of a ruling regime; it may contribute to the legitimisation of spreading hateful remarks often targeting minority groups, which

22 Eric Fripp, Nationality and Statelessness in the International Law of Refugee Status (Bloomsbury 2014) 30-31 [1.55].

23 Paul Weis suggests that the denationalisation of individuals as a penal measure may be traced back to Roman law, which is nonetheless a largely twentieth century phenomenon based on political and national cohesion. See Paul Weis, Nationality and Statelessness in International Law (2 $2^{\text {nd }}$ edn, Springer 1979) 117-20. See also Lindsey N Kingston, 'Worthy of Rights: Statelessness as a Cause and Symptom of Marginalisation' in Tendayi Bloom, Katherine Tonkiss and Phillip Cole (eds), Understanding Statelessness (Routledge 2017) 17. ibid.

25 By doing so such ruling regimes choose to ignore the avoidance of statelessness, which has become a general principle of customary international law and therefore binding on all states - irrespective of being a state party to either of the UN Statelessness Conventions and thus violating their international legal obligations. See Convention Relating to the Status of Stateless Persons, opened for signature 28 September 1954, 360 UNTS 117 (entered into force 6 June 1960); Convention on the Reduction of Statelessness, opened for signature 30 August 1961, 989 UNTS 175 (entered into force 13 December 1975). See also Kingston (n 23); Michelle Foster and Hélène Lambert, International Refugee Law and the Protection of Stateless Persons (Oxford University Press 2019). Arbitrary Deprivation of Nationality: Report of the Secretary-General, UN Doc A/HRC/10/34 (26 January 2009); European Convention on Nationality, opened for signature 6 November 1997, ETS 166 (entered into force 1 March 2000) annex ('Explanatory Note') [33], [34]; Council of Europe Convention on the Avoidance of Statelessness in Relation to State Succession, opened for signature 19 May 2006, CETS 200 (entered into force 1 May 2009) annex ('Explanatory Note') [1].

26 Andrew Whiteley, 'Minorities and the Stateless in Persian Gulf Politics (1993) 35(4) Survival $28,46$.

27 Dominic McGoldrick, 'Accommodating National Identity in National and International Law' in Stephen Tierney (ed), Accommodating National Identity: New Approaches in International and Domestic Law (Martinus Nijhoff 2000) 13, 16-17.

28 Wilhelm Heitmeyer et al (eds), Control of Violence: Historical and International Perspectives on Violence in Modern Societies (Springer 2011) 489. 
can lead in and of itself to the escalation of violence against a social group, especially minorities. Hate speech has various implications on the enjoyment of human rights for both individuals and minorities, which is why addressing hate speech requires a coordinated response that tackles the root causes and drivers of hate speech, as well as its impact on victims and societies more broadly.

In the lack of popular representation, the human rights of persons belonging to minorities (including the human right to a nationality) are not sufficiently addressed or taken into account when making decisions affecting their lives in areas, including nationality issues. ${ }^{29}$ Such is the case when groups such as the Rohingya - a religious, ethnic and linguistic minority in Myanmar - are sometimes described in public discourses as a people, a group, or a community, but not necessarily as a minority. This may be due to the lack of an agreed upon definition for minorities and their related status and rights. Therefore, it is of pivotal importance to raise awareness on minorities as particularly affected by statelessness, hate speech and other areas of human rights concerns, as pointed out by the current UN Special Rapporteur on minority issues in its recent report. ${ }^{30}$

\section{ETHNIC DISCRIMINATION LIES AT THE CORE OF STATELESSNESS IN ASIA}

As one of the most ethnically diverse regions in the world, the Asian continent is home to large indigenous minority populations, as well as non-indigenous minorities through ever-changing legal and illegal migrant flows, ${ }^{31}$ leaving states the challenging task to manage their historically, culturally and religiously diverse societies burdened by a colonial heritage. According to UNHCR estimations, 40 per cent of the world's identified stateless population live in Asia and the Pacific, highlighting profound protection needs. ${ }^{32}$ Looking at some parts of Asia, we find that discriminatory nationality laws (on the basis of gender, race or religion) are major reasons for the prevalence of statelessness on the continent. ${ }^{33}$ Whereas the Rohingya are one of the best known cases of statelessness in Southeast Asia, there are other stateless populations not to be forgotten in the regional statelessness context. For instance, in Myanmar, in addition to the Rohingya, at least 500,000 persons of Indian origin are also effectively stateless, while in Thailand - despite significant recent developments - approximately 400000 mostly indigenous 'hill tribe' people living in

29 Andrew Whiteley, 'Minorities and the Stateless in Persian Gulf Politics' (1993) 35(4) Survival 28, 45-46.

30 Fernand de Varennes, Minority Issues: Report of the Special Rapporteur on Minority Issues, UN Doc A/HRC/40/64 (9 January 2019) [7] ('Minority Issues Report').

31 Michelle Ann Miller, 'Introduction — Ethnic minorities in Asia: Inclusion or exclusion?' (2011) 34(5) Ethnic and Racial Studies 751.

32 Marie McAuliffe, 'Protection Elsewhere, Resilience Here: Introduction to the Special Issue on Statelessness, Irregularity, and Protection in Southeast Asia' (2017) 15(3) Journal of Immigrant and Refugee Studies 221.

33 'Stateless Persons in Asia and the Pacific', Institute on Statelessness and Inclusion (Web Page, 2017) <http://www.worldsstateless.org/continents/asia/stateless-persons-in-asia-andthe-pacific $>$. See also Report on statelessness in South and South East Asia (Report, 2016/2220(INI), European Parliament Committee on Foreign Affairs 4 May 2017) $<$ https://www.europarl.europa.eu/doceo/document/A-8-2017-0182_EN.html>. 
mountainous regions bordering countries such as Myanmar, Cambodia and Laos continue to lack citizenship. ${ }^{34}$

Systematic discrimination against ethnic minorities, denationalisation and resulting statelessness are age-old phenomena on the Asian continent. ${ }^{35}$ Regrettably some stereotypes, stigmas and perceptions relating to certain minorities are deeply rooted in some Asian countries, which are very difficult to challenge in public discourse both online and offline. ${ }^{36}$ Nonetheless, the continued practice of hate speech against minorities in Asian societies - now also spread on the internet - is very harmful, as it can jeopardise entire societies in Asia through the incitement of violence against minorities. In cases left unaddressed, hate speech can effectively prevent reconciliation, social inclusion and coexistence in many Asian countries and with technological development - where Asian countries are active drivers - and the global increase of users on social media platforms, hateful and degrading speech against minority groups is also gradually moving to the online space where users enjoy a high degree of anonymity.

On the other hand, Asian countries, which have diverse societies, typically have few effective anti-hate speech laws in place that would criminalise online and offline hate speech. ${ }^{37}$ The adoption of strongly crafted anti-hate speech laws could convey a clear message to perpetrators of their potential individual criminal liability, which could promote the acquis of respectful and integrated societies.

\section{Ethnic Koreans SubJect to Mass Denationalisation and Hate}

\section{SPEECH IN JAPAN}

A long forgotten example of mass denationalisation in East Asia is the ethnic Koreans who were forcibly taken to Japan during World War II to serve Japan. While Japanese nationality was imposed on the entire Korean people after the annexation of Korea in 1910, after World War II, Japan 'resorted to mass denationalisation of Koreans by depriving Koreans then residing in Japan of their Japanese nationality' under the Alien Registration Law of 1952 who then became stateless. ${ }^{38}$ When Japan normalised its relationship with South Korea in 1965,

34 See 'Thousands of Stateless People Given Nationality in Thailand', UNHCR (Web Page) $<$ https://www.unhcr.org/ibelong/thousands-of-stateless-people-given-nationality-inthailand/>. See also Janepicha Cheva-Isarakul, "Diagnosing" Statelessness and Everyday State Illegibility in Northern Thailand' (2019) 1(2) Statelessness \& Citizenship Review 214.

35 See Fernand de Varennes, 'The Rights of the Marginalized in Asia: Increasing Protection or Vulnerability?' in Fernand de Varennes and Christie M Gardiner, Routledge Handbook of Human Rights in Asia' (Routledge 2019) 1. 'Minority Stories/Asia', Minority Rights Group $<$ http://stories.minorityrights.org/statelessness/chapter/asia/>.

36 Rita Manchanda, The No Nonsense Guide to Minority Rights in Asia (SAGE 2009) 16-17. Moonis Ahmar, The Challenge of Confidence-Building Measures in Southeast Asia (HarAnand 2001) 67.

37 Unlike for instance in Germany and France which recently drafted anti-hate speech laws that allow the regulators to impose large fines on social media platforms if they fail to report hate speech to the police and remove hateful postings. See Netzwerkdurchsetzungsgesetz [Act to Improve Enforcement of the Law in Social Networks] (Germany) 1 October 2017, BGBI I, 2017, 3352; Entwurf eines Gesetzes zur Bekämpfung des Rechtsextremismus und der Hasskriminalität [Draft Law to Combat Right-Wing Extremism and Hate Crime] (Germany) 26 February 2020 Gesetzentwurf der Bundesregierung. See also Draft Law Aimed at Combating Hate Content on the Internet (France) 9 July 2019, No 310. See also Myungkoo Kang et al, Hate Speech in Asia and Europe: Beyond Hate and Fear (Routledge 2020).

38 Swan Sik Ko, Nationality and International Law in Asian Perspective (Martinus Nijhoff 1990) 297; Alien Registration Law (Japan) Law No 125 of 1952. 
stateless Koreans had the chance to apply for South Korean citizenship and relocate there, but many refused and, thus, continued to live in statelessness. ${ }^{39}$ This changed in 1991 when they were granted special resident status in Japan as 'Korean' became an option for 'nationality' on alien registration documents. ${ }^{40}$ As such, Koreans living in Japan were urged to choose an ideological position between South and North Korea, and in the absence of a positive affirmation of 'South Korean' nationality, these ethnically Korean persons either became stateless or were considered effectively 'North' Koreans, though their legal status remained 'stateless'. ${ }^{41}$ Ethnic Koreans residing in Japan ('zainichi Koreans') have been suffering from systematic discrimination ever since their settlement in Japan during colonial times, ${ }^{42}$ which used to serve to reinforce the ethnic prejudice that Koreans were culturally and 'racially' inferior to Japanese. These long-term harmful implications continue to prevail in Japanese society. Despite tensions seemingly decreasing after the 1960 s, and class becoming a more prevalent factor than ethnicity in the Japanese social hierarchy, ${ }^{43}$ manifestations of hate speech resurfaced in the 2000s.

Ten years ago, members of an ultra-nationalist group, the Association of Citizens against the Special Privileges of Zainichi Koreans ('Zaitokukai'), hurled hateful messages in front of an elementary school attended by Korean children in Kyoto on 4 December 2009, which constituted the first step in a series of intimidating demonstrations conveying hateful propaganda messages targeting ethnic minorities - mainly zainichi Koreans. ${ }^{44}$ Already then, perpetrators relied on the internet to spread their hateful messages. ${ }^{45}$ What is more, the mentioned extremist association used the internet heavily to exchange information and organise themselves. ${ }^{46}$

Since the perpetrators were not brought to justice, similar atrocities continued and magnified in size. ${ }^{47}$ Racist groups have been spreading their messages both nationally and internationally through the dissemination of video recordings showing demonstrations on the internet. ${ }^{48}$ Although some members of racist

39 Sonia Ryang, Koreans in Japan: Critical Voices from the Margin (Routledge 2000) 4. See also Treaty on Basic Relations, Japan-Korea, 583 UNTS 45 (signed and entered into force 22 June 1965).

40 Miki Y Ishikida, Living Together: Minority People and Disadvantaged Groups in Japan (iUniverse 2005) 48.

41 There is no form of North Korean nationality recognised at any level of Japan's legal and juridical system, since North Korea is not recognised by the Japanese state. As of June 2018, according to the Japanese Justice Ministry's data 30,181 individuals continued to live in Japan without any official nationality. See Ryang (n 39) 4-11; Park Ji-won, 'Hate Speech against Koreans Still Active in Japan', The Korea Times (online, 24 March 2019) $<$ https://www.koreatimes.co.kr/www/nation/2019/03/120_265876.html>.

42 According to Bumsoo Kim, tensions gradually decreased after the 1960 s and with the economic boom of the Japanese economy ethnic Koreans could succeed more and change and get to a 'higher class', which decreased their inequality gradually: Bumsoo Kim, 'Bringing Class Back in: The Changing Basis of Inequality and the Korean Minority in Japan' (2008) 31(5) Ethnic and Racial Studies 871, 876-84.

43 ibid 880.

44 See Kenichiro Ito, 'Anti-Korean Sentiment and Hate Speech in the Current Japan: A Report from the Street' [2014] (20) Procedia Environmental Sciences 434, 438.

45 ibid 441.

46 Report on the Issue of Racism and Hate Speech in Japan (Report, Committee on the Protection of Human Rights of the Central Head Office of the Korean Residents Union in Japan, 18 July 2014) 11.

47 ibid 5-7.

48 ibid 13. 
groups faced criminal prosecution for their misconduct, no case has been adjudged by a court to be an act of racial discrimination, which implies a sense of impunity that has contributed to the harmful persistence of legitimised hate speech and violence against them. ${ }^{49}$

Regrettably, the Government of Japan has strengthened institutionalised discrimination against ethnic Koreans by not taking any concrete action against the perpetrators and, thus, potentially legitimising discrimination against ethnic Koreans in racist groups and individuals through inaction. ${ }^{50}$ While there was a lack of anti-hate speech laws until 2016 when Japan passed its Act on the Promotion of Efforts to Eliminate Unfair Discriminatory Speech and Behavior against Persons Originating from outside Japan, ${ }^{51}$ anti-racist protesters vocally condemned hate speech against Koreans on numerous occasions. ${ }^{52}$ At the time, there may have also been a lack of understanding of the hate speech context and how it interferes with human rights standards - the government might have also found it difficult to respond to the new challenges posed by hate speech spread in the online space. Nonetheless, the root causes and hideous nature of hate speech spread against the ethnic Koreans in Japan in the early 2010s provides us with an important background on the recent and ongoing incidents of hate speech targeting minorities spreading on the internet. As this article is being written, there is now a realm of tools and policies that can assist state actors and decision-makers to tackle hate speech that is spread online. This incident revealed that putting in place and duly implementing anti-hate speech laws, carrying out capacity-building of law enforcement actors on hate crimes and bringing perpetrators to justice are essential elements of addressing hate crimes against minorities both online and offline.

\section{Hate Speech against the Stateless Rohingya Facilitated by}

\section{FACEBOOK: LESSONS LEARNED?}

The Rohingya are a stateless Indo-Aryan ethnic group who mostly follow Islam religion, but also include a minority group that practice Hinduism, and reside in Rakhine State in Myanmar where most citizens are otherwise Buddhist. There, Rohingya are often considered to be 'Bengalis' from neighbouring Bangladesh although their families have lived in the country for generations. ${ }^{53}$ The Rohingya constitute the largest stateless minority group in Myanmar, and were repeatedly forced to leave their home country in the past years due to persecution as an ethnic and religious (Muslim) minority group and various forms of human rights

49 Ayako Hatano, 'Can Strategic Human Rights Litigation Complement Social Movements? A Case Study of the Movement against Racism and Hate Speech in Japan' (2019) 14(2) University of Pennsylvania Asian Law Review 228, 242.

50 Taisuke Komatsu (Oral Statement, $7^{\text {th }}$ Session of the Forum on Minority Issues, 25 November 2014).

51 The Act passed in 2016 presents important shortcomings, as it does not ban hate speech nor penalise the act of hate speech. See Honpōgai shusshinsha ni taisuru futō na sabetsuteki gendō no kaishō ni muketa torikumi ni kansuru hōritsu [The Act on the Promotion of Efforts to Eliminate Unfair Discriminatory Speech and Behavior against Persons Originating from Outside Japan] (Japan) Law No 68 of 2016 The Act's official translation can be found at: $<$ http://www.moj.go.jp/content/001199550.pdf>.

52 See Ito (n 44) 442.

53 Sabyasachi Basu Ray Chaudhury and Ranabir Samaddar, The Rohingyas in South Asia: People Without a State (Routledge 2018). 
violations. ${ }^{54}$ In the light of Myanmar's 1982 Burma Citizenship Law ('Burma Citizenship Law') (still in effect) ${ }^{55}$ citizenship may be conferred by birth to members of 135 listed ethnic groups which is a clear act of ethnic based discrimination. ${ }^{56}$ As a result of the Burma Citizenship Law, over 700,000 Rohingya people were arbitrarily deprived of their nationality as early as 1982, and were also denied freedom of movement and other basic rights. ${ }^{57}$ As they do not fully enjoy the right to access to justice, let alone the right to a fair trial, the Rohingya have been facing severe and repeated human rights violations for almost half a century, while perpetrators have not been brought to justice making it difficult for victims to heal. ${ }^{58}$

Following sectarian violence between Arakanese and Rohingya populations in Myanmar, the government installed harsh restrictions on the provision of humanitarian aid, which have been subsequently tightened as time goes on. ${ }^{59}$ After the 'clearance operations' that began on 25 August 2017, launched by Myanmar's military in Rakhine State in response to an attack by a Rohingya insurgent group, a number of security checkpoints were established across Rakhine State with increased security and patrolling. ${ }^{60}$ Those failing to provide the requisite travel documents at these checkpoints risk arrest, detention and imprisonment. Many have suffered unspeakable abuses (the burning of houses and other property to ashes, massacres, rapes and other forms of gender-based violence). ${ }^{61}$ Over the course of recent years, many Rohingya have managed to flee to Bangladesh, Japan, Saudi Arabia, India and Malaysia where they live as refugees or illegal migrants, vulnerable to deportation and to live under marginalised conditions. A recently adopted UN report summarises the key findings of the independent and international fact-finding mission on Myanmar presented to the UN Human Rights Council in 2019, and confirmed that approximately 600,000 Rohingya remained in northern Rakhine State (which shares a border with Bangladesh).

They continue to be subjected to discriminatory policies and practices, including segregation and severe restrictions on their movements; deprivation of citizenship; denial of economic, social and cultural rights; physical assaults constituting torture or other cruel, inhuman or degrading treatment or punishment; arbitrary arrest; and, in some areas, hostility from members of ethnic Rakhine communities that the mission found also to constitute persecution and other prohibited crimes against humanity. ${ }^{62}$

The situation of the Rohingya in Myanmar gives a detailed picture of how an ethnic and religious (Muslim) minority group became first disfavoured and then

54 ibid.

551982 Burma Citizenship Law (Myanmar) Pyithu Hluttaw Law No 4 of 1982.

56 This has been reported by Kawser Ahmed and Helal Mohiuddin, The Rohingya Crisis: Analyses, Responses, and Peace Building Avenues (Lexington Books 2019) 24. Here, the authors note that the first official list was produced just before the 2014 census.

57 'From Discrimination to Ethnic Cleansing — The Fate of Myanmar's Stateless Rohingya', Minority Stories (Web Page) <http://stories.minorityrights.org/statelessness/chapter/fromdiscrimination-to-ethnic-cleansing-the-fate-of-myanmars-stateless-rohingya/>.

58 See Access to Justice in Crisis: Legal Empowerment for Rohingya Refugees Living in Cox's Bazar, Bangladesh (Report, International Rescue Committee October 2019).

59 Report of the Independent International Fact-Finding Mission on Myanmar, UN Doc A/HRC/39/64 (12 September 2018) 7 ('IIFFM Report Myanmar 2018').

60 Report of the Independent International Fact-Finding Mission on Myanmar, UN Doc A/HRC/42/50 (8 August 2019) 13 [77] ('IIFFM Report Myanmar 2019').

61 See ibid 6 [27].

62 ibid $12-13[76]$. 
denationalised. As this article highlights below, the resultant domestic discourse inspired state-sponsored hate speech (well before the 'clearance operation' took place), both online and offline. Once hate speech was legitimised, the Rohingya were persecuted and eventually subject to ethnic cleansing in the twenty-first century. ${ }^{63}$ The international community has been following the ongoing abuses against the Rohingya in Myanmar and have adopted a number of human rights resolutions. ${ }^{64}$ The affirmations have been received with a lack of cooperation on the part of the government of Myanmar, and relatively little has been achieved by the international community to save the Rohingya from mass severe human rights violation. ${ }^{65}$ A report from the Independent International Fact-Finding Mission on Myanmar ('the Mission') found that hate speech against the Rohingya played a pivotal and ongoing role in discrimination against the Rohingya. Online hate speech continues to be disseminated on social media platforms, especially on Facebook, ${ }^{66}$ used as a means to incite violence against the Rohingya. ${ }^{67}$

The Mission reported on heightened tension immediately before the launch of the 'clearance operation' of 25 August 2017. It noted the increase in Myanmar media attention on the activity of the Arakan Rohingya Salvation Army and commented on the ongoing state-sponsored hate-speech towards the Rohingya. ${ }^{68}$ At the peak of the Rohingya crisis, Facebook was heavily criticised for not employing any Burmese-speakers who would have been able to detect and remove hate speech related content from Facebook and to moderate some of the discussions in Burmese, despite applying various tools for content moderation, including editorial review, automatic detection and community flagging). ${ }^{69}$ It is important to point out that for many people in this emerging economy, Facebook is the primary website they use to connect and get information. In its report published in 2018 the Mission also suggested that Facebook had been used to facilitate the spread of hate speech online that may have contributed to the escalation of violence against the Rohingyas in Myanmar.

63 'Myanmar's Rohingya Persecuted, Living under Threat of Genocide, UN Experts Say' (Press Release, $16 \quad$ September $<$ https://www.ohchr.org/EN/NewsEvents/Pages/DisplayNews.aspx?NewsID=24991\&LangI $\mathrm{D}=\mathrm{E}>$; “"Ethnic Cleansing” of Myanmar's Rohingya Continues: UN' Bangkok Post (online, 6 March 2018) <https://www.bangkokpost.com/world/1423338/ethnic-cleansing-ofmyanmars-rohingya-continues-un>.

64 See, eg, Situation of Human Rights in Myanmar, UN Doc A/HRC/RES/34/22 (3 April 2017); Situation of Human Rights in Myanmar, UN Doc A/C.3/73/L.51 (31 October 2018); Situation of Human Rights of Rohingya Muslims and Other Minorities in Myanmar, UN Doc A/HRC/RES/39/2 (3 October 2018); IIFFM Report Myanmar 2019 (n 60); Situation of Human Rights in Myanmar, UN Doc A/C.3/72/L.48 (31 October 2017).

65 In 2017 the Government of Myanmar declared not to cooperate with the Independent International Fact-Finding Mission on Myanmar, nor with the Special Rapporteur on the situation of human rights in Myanmar.

66 Whereas Facebook removed such pages, unofficial pages supporting hate speech against the Rohingya remain active. See IIFFM Report Myanmar 2019 (n 60) 12 [72].

67 See Billy Perrigo, 'Facebook Was Used to Incite Violence in Myanmar: A New Report on Hate Speech Shows It Hasn’t Learned Enough Since Then', Time (online, 29 August 2019) <eahttps://time.com/5712366/facebook-hate-speech-violence/>.

68 IIFFM Report Myanmar 2018 (n 59).

69 See Michael Safi, 'Revealed: Facebook Hate Speech Exploded in Myanmar during Rohingya Crisis', The Guardian (online, 3 April 2018) $<$ https://www.theguardian.com/world/2018/apr/03/revealed-facebook-hate-speechexploded-in-myanmar-during-rohingya-crisis >; Tom Miles, 'UN Investigators Cite Facebook Role in Myanmar Crisis', Reuters (online, 12 March 2018) $<$ https://www.reuters.com/article/us-myanmar-rohingya-facebook/u-n-investigators-citefacebook-role-in-myanmar-crisis-idUSKCN1GO2PN>. 
The Bengali population exploded and the aliens tried to seize the land of local ethnics. ... Race cannot be swallowed by the ground but only by another race. All must be loyal to the State in serving their duties, so that such cases will never happen again. ${ }^{70}$

This statement was posted on Facebook directly by a member of the Myanmar political hierarchy — the Commander-in-Chief of Myanmar, first Senior General Min Aung Hlaing on 21 September 2017. One year later, at the height of the 'clearance operations' on 2 September 2018, in yet another Facebook post, Aung Hlaing further suggested that

the Bengali problem was a longstanding one which has become an unfinished job despite the efforts of the previous governments to solve it. The government in office is taking great care in solving the problem. ${ }^{71}$

Considering the atrocities that followed the 'clearance operations', it may be assumed that such dehumanising messages coming from the Myanmar hierarchy could have served as a legitimising factor in the escalation of violence for nationalists to spread hateful posts building on the government's proclaimed intention to 'solve the problem'. Therefore, there may be a reason to suspect that not removing similar harmful content from Facebook - coming from prominent public figures in Myanmar - might have played a key role in facilitating and amplifying the incitement of violence against the Rohingyas.

The report introduced by the Mission stated that:

The mission is deeply disturbed by the prevalence of hate speech, offline and online, often including advocacy of national, racial or religious hatred constituting incitement to discrimination, hostility or violence. This has accompanied outbreaks of violence, especially in Rakhine State. Dehumanising and stigmatising language against the Rohingya, and Muslims in general, has for many years been a key component of the campaign to 'protect race and religion', spearheaded by extremist Buddhist groups like MaBaTha. ${ }^{72}$

The report emphasises the key role of social media, especially Facebook which has been used as a tool to spread hate, in a context where, for most users, Facebook is the entire internet. ${ }^{73}$ Acknowledging the improvements made by Facebook, the report suggests that the response of Facebook was slow and ineffective, expressing regret that Facebook was unable to provide country-specific data about the spread of hate speech on its platform. ${ }^{74}$

The hearing of Facebook CEO Mark Zuckerberg in front of the United States Senate that took place in April 2018 concerned a number of issues related to the sharing of personal data and misinformation, but also touched upon Facebook's responsibility in providing a platform to incite violence in Myanmar. In his response to Vermont Senator Patrick Leahy, Zuckerberg said that '[w]hat's happening in Myanmar is a terrible tragedy, and we need to do more', admitting that Facebook mostly relies on artificial intelligence to identify hate speech and

70 IIFFM Report Myanmar 2018 (n 68) 14, quoting Min Aung Hlaing, 'Gallant Efforts to Defend the HQ against Terrorist Attacks and Brilliant Efforts to Restore Regional Peace, Security Are Honoured' (Facebook Post, 21 September 2017) (Deleted).

71 IIFFM Report Myanmar 2018 (n 68) [35], quoting Min Aung Hlaing (Facebook Post, 2 September 2018) (Deleted).

72 ibid 14 [73].

73 ibid 14 [74].

74 ibid. 
pledged to deploy dozens of Burmese-language moderators to ensure that Facebook would not be used for similar purposes in the future. ${ }^{75}$

A recent report entitled An Independent Assessment of the Human Rights Impact of Facebook in Myanmar ${ }^{76}$ looked into Facebook's responsibility in spreading online hate and inciting offline violence against the Rohingyas in Myanmar concluding that Facebook was not doing enough to help prevent its platform from being used to foment division and incite offline violence, agreeing that Facebook can and should do more to prevent such acts, and stated having had 'invested heavily in people, technology and partners to address the abuse of Facebook in Myanmar'. ${ }^{77}$ The report also set out some recommendations to advise Facebook on mitigating the adverse human rights impact, while maximising the opportunities for freedom of expression, digital literacy, and economic development. ${ }^{78}$

In order to follow up on BSR's recommendations, Facebook has put in place a team with native Myanmar language speakers who have a better understanding of the country context to work on issues specific to Myanmar, reviewing content, as well as 'improving the development and enforcement of [their] policies' ${ }^{79}$ Additionally, Facebook has undertaken to understand how content that does not otherwise breach their internal guidelines may have the potential to incite offline violence, alongside an update to its credible violence policy for the removal of misinformation that contributes to violence. On an operational level, Facebook sought to improve their detection capacity by engaging in more proactive detection of hate speech in Myanmar, and taking an aggressive stance on the deletion of accounts that mislead others about who they represent to be. ${ }^{80}$ As part of these steps towards the identification of violence, Facebook also invested in the extended use of artificial intelligence, allowing their software to engage posts that contain 'graphic violence and comments that are violent and dehumanising' while reducing their distribution as they are investigated by the Facebook Community Operations team, who verify whether the given content violates Facebook policies and remove that content to limit its visibility. ${ }^{81}$

Four months after Facebook CEO Mark Zuckerberg's commitment to address content moderation expressed in front of the US Senate, Reuters still found more than '1,000 examples of Facebook posts, comments and pornographic images' regarding the Rohingya and other Muslims calling them such names as 'dogs',

75 Adam Taylor, 'The Big Questions for Marc Zuckerberg on Facebook's Role in Burma', Washington Post (online, $10 \quad 10$ April $<$ https://www.washingtonpost.com/news/worldviews/wp/2018/04/10/the-big-questions-formark-zuckerberg-on-facebooks-role-in-burma/>; Anthony Kuhn, 'Concern Is High Over Facebook's Role in Fanning Violence in Myanmar', NPR (online, 14 June 2018) $<$ https://www.npr.org/2018/06/14/619854631/concern-is-high-over-facebooks-role-infanning-violence-in-myanmar? $\mathrm{t}=1591748452826>$.

76 Alex Warofka, An Independent Assessment of the Human Rights Impact of Facebook in Myanmar (Report, Facebook 5 November $<$ https://about.fb.com/news/2018/11/myanmar-hria/>. The assessment - according to the report - 'was completed by Business for Social Responsibility — an independent non-profit organisation with expertise in human rights practices and policies'.

77 ibid.

78 ibid: (1) building on existing governance and accountability structures, (2) improving enforcement of content policies, (3) increasing engagement with local stakeholders, (4) advocating for regulatory reform and (5) preparing for the future.

79 ibid.

80 ibid.

81 ibid. 
'maggots', and 'rapists', revealing that the social media giant continued to struggle with content moderation, heavily relying on its users who report posts including hate speech, mainly because its automated systems struggle to interpret Burmese texts. ${ }^{82}$ One year later in its subsequently adopted Detailed Findings of the Independent International Fact-Finding Mission on Myanmar, the Mission acknowledged that Facebook banned dangerous organisations (the Arakan Army, the Myanmar National Democratic Alliance Army, Kachin Independence Army and the Ta'ang National Liberation Army) from the platform, as well as all related praise and support. ${ }^{83}$ Indeed, this constituted a milestone in addressing the escalation of violence against the Rohingyas fuelled by hate speech online.

\section{Hate Speech against Minorities in the State of Assam, India:}

\section{LESSONS IGNORED}

A regional parallel may be drawn between the mass disenfranchisement of the Rohingya people in Myanmar and another unfolding statelessness crisis in the State of Assam, India. This situation has developed since August 2019, when the Indian government published its final list of citizens in the north-eastern Indian State of Assam - stripping nearly 2 million people of Muslim origin of their Indian citizenship, an event noted by the UN Special Rapporteur on Minority Issues in their recent report on minorities affected by statelessness. ${ }^{84}$

On 31 August 2019 India published the final version of a list of citizens - the National Register of Citizens ('NRC') — which was updated for the first time since its creation in 1951 and stripped approximately 1.9 million people of their Indian citizenship in the north-eastern Indian State of Assam. ${ }^{85}$ The NRC was created to determine who was born in Assam and is therefore Indian and who might be a migrant from neighbouring Bangladesh, constituting a list of those who can prove they came to the state by 24 March 1971, the day before neighbouring Bangladesh declared independence from Pakistan. ${ }^{86}$ The governing Bharatiya Janata Party ('BJP') considered this act as a legal way of eliminating 'infiltrators' from the country - mainly illegal immigrants from bordering Bangladesh, many believed to be from the Bengali-speaking minority. ${ }^{87}$ It may be the case that the Hindu-nationalist government wants to make Assam a 'test case' for Hindu primacy in India by expelling 'illegal' Muslim migrants who they see as 'infiltrators', which was one of the electoral issues addressed prior to elections by the government. Families living in the State of Assam have been required to

82 Hatebook (n 9).

83 Detailed Findings of the Independent International Fact-Finding Mission on Myanmar, UN Doc A/HRC/42/CRP.5 (16 September 2019) 86-87 [272]. See also 'Banning More Dangerous Organizations from Facebook in Myanmar', Facebook (Web Page, 5 February $2019)<$ https://newsroom.fb.com/news/2019/02/dangerous-organizations-in-myanmar/>.

84 Minority Issues Report (n 30) 13 [86].

85 Christoph Sperfeldt and Amelia Walters, 'A Crisis of Citizenship in India is Risking Mass Statelessness', Pursuit (online, 5 September 2019) $<$ https://pursuit.unimelb.edu.au/articles/acrisis-of-citizenship-in-india-is-risking-mass-statelessness $>$.

86 More precisely, this deadline indicates the day before the beginning of the Bangladesh Liberation War, when what was then East Pakistan declared independence from West Pakistan. As a result of the war, an estimated 10 million refugees from the newly formed People's Republic of Bangladesh fled to India whose descendants live there today. See Rajini Vaidyanathan, 'Assam NRC: What Next For 1.9 Million "Stateless" Indians?', $B B C$ (online, 31 August 2019) <https://www.bbc.com/news/world-asia-india-49520593>. ibid. 
provide documentation about their lineage so those who are not able to prove their citizenship will be deemed illegal foreigners in India and will be denied their citizenship rights. Assamese residents subject to this citizenship determination procedure can appeal to specially formed courts known as 'Foreigner Tribunals' ('FT') as well as, theoretically, the High Court and the Supreme Court of India. ${ }^{88}$ However, the validity of the process by which these FT engage cases is a topic of contemporary debate, and Assam residents face a potentially long and exhausting appeals process. ${ }^{89}$ Upon them weighs the consideration of whether they would be able to bear the inherent charges of appeals in case they lose their case, the possibility of being detained in detention centres located in prisons indefinitely or even be deportation from the country. ${ }^{90}$

While this unilateral act has not yet rendered millions of Muslim residents of Assam stateless - it definitely has the potential to and also to inflame HinduMuslim tensions in the region, which may cause regional instability and may even lead to radicalisation. The arbitrary action of the Indian (Hindu) government is often compared to the approach of the Buddhist campaign against the Rohingya Muslims in Myanmar, forcing more than 700,000 to flee their homes and seek refuge in neighbouring countries. ${ }^{91}$ Likewise, in Hindu-majority India, Muslim minorities have faced a series of attacks since the current government entered into power. In the Indian context it must be noted that ethnic discrimination has a historical background that indicates illegal migration as one of the key factors of ethnic conflicts and political unrest in the State of Assam (neighbouring with Bangladesh) for decades, as the Hindu-Assamese fear of being dominated by 'foreigners' is rooted very deeply. ${ }^{92}$

Similar to the Myanmar scenario, high-ranking Indian government officials began to publicly make hateful comments on Bengali and other (mostly Muslim) minorities living in the State of Assam in India. As mentioned, in India illegal migration has been a contributing factor to ethnic conflict and political unrest in the State of Assam for decades, stemming from the Assamese fear of being dominated by foreigners. ${ }^{93}$ With the rise of the BJP currently in power, these negative sentiments have been amplified. The situation of being left out of the NRC has been affecting those concerned very heavily, also leading to the suicide of some of those who have been excluded from the published list of citizens, fearing indefinite detention, deportation from India and consequences of statelessness. ${ }^{94}$

88 Talha Abdul Rahman, 'Identifying the "Outsider": An Assessment of Foreigner Tribunals in the Indian State of Assam’ (2020) 2(1) Statelessness \& Citizenship Review 112.

89 ibid.

90 ibid.

91 Debasish Roy Chowdhury, 'Abandoned in Assam: India Creates Its Own Rohingya, and Calls Them "Bangladeshi",, South China Morning Post (online, 23 August 2019) $<$ https://www.scmp.com/week-asia/society/article/3024155/assam-edge-indias-rohingyamoment-threatens-millions-modis-hindu>.

92 Sandhya Goswami, 'Ethnic Conflict in Assam' (2001) 62(1) The Indian Journal of Political Science 123-37; Pranati Datta, 'Push-Pull Factors of Undocumented Migration From Bangladesh to West Bengal: A Perception Study' [2004] (June) The Qualitative Report $<$ http://library.isical.ac.in:8080/jspui/bitstream/10263/2930/1/Binder1.pdf $>$.

93 ibid.

94 Subir Bhaumik, 'Assam NRC: Are India's 'Unwanted People’ Being Driven to Suicide', $B B C$ (online, 28 June 2019) <https://www.bbc.com/news/world-asia-india-48754802>; 'Shoot the Traitors' - Discrimination against Muslims under India's New Citizenship Policy (Report, Human Rights Watch 9 April 2020) < https://www.hrw.org/report/2020/04/10/shoottraitors/discrimination-against-muslims-under-indias-new-citizenship-policy>. 
Despite all the commitments expressed in November 2018, shortcomings in content moderation continued to persist on Facebook as revealed by recent incidents in Assam. ${ }^{95}$ Perhaps failing to learn from the Rohingya crisis, Facebook has not quite managed to overcome the challenges imposed by the obligation and responsibility of moderating hateful comments and graphic content in the wake of the BJP's update to the NRC. According to global online advocacy group Avaaz, Bengali Muslims in particular seem to have become targets of online hate speech on Facebook, presenting Facebook posts calling Bengali Muslims 'parasites' ${ }^{96}$ 'dogs' ${ }^{97}$ and 'rapists', 98 and urging for their extermination, ${ }^{99}$ which constitute very dangerous messages carrying harmful connotations that may have negatively shaped public perception of and discourse on Bengali Muslims in Assam. According to Avaaz, these hateful posts have been seen by more than 5.4 million viewers, calling into question the success of the new approach taken by Facebook since it was used to incite online hate speech during the 2017 Rohingya genocide and whether Facebook's systems to detect hate speech in languages other than English is working efficiently. ${ }^{100}$ In October 2019, Avaaz published a report Megaphone for Hate: Disinformation and Hate Speech on Facebook during Assam's Citizenship Count ${ }^{101}$ focusing on hate speech in the Assamese language, suggesting that Facebook was too reliant on artificial intelligence in its hate speech detection mechanisms, and that Facebook needed to put in place more human-led teams to be able to effectively monitor content in Assam. ${ }^{102}$ In the investigation of hate speech against ethnic minorities living in the State of Assam, with the help of native Assamese speakers, Avaaz analysed 800 Facebook posts and comments linked to Assam and the NRC, applying keywords from the immigration discourse in Assamese language, and then assessed them using the three tiers of prohibited hate speech set forth in Facebook's Community Standards. ${ }^{103}$ This analysis found that at least 26.5 per cent of the explored posts and comments effectively amounted to hate speech, and that those that did were shared on the social media platform 99,650 times, having been viewed nearly 5.4 million times without being deleted by Facebook. According to Avaaz, of the 213 examples they flagged as hate speech, Facebook has deleted only 96 in violation of its Community Standards. ${ }^{104}$ The report presents one case where one individual inciting hatred against Bengali Muslims had his page removed by Facebook at least seven times, only to set up

95 Results of a recent study investigating Facebook's hate speech removal process indicated that only about half of reported content containing hate speech was removed following the 2018 policy change, suggesting that Facebook continued to face challenges in removing misogynistic hate speech, establishing consistency in removing attacks and threats, considering context in removal decisions. See Caitlin R Carlson and Hayley Rousselle, 'Report and Repeat: Investigating Facebook's Hate Speech Removal Process' (2019) 25(23) First Monday <https://firstmonday.org/ojs/index.php/fm/article/view/10288/8327>.

96 Megaphone for Hate (n 1) 30, citing Anonymous (Facebook Post, July 2019) (emphasis added). See also at 64.

97 Megaphone for Hate (n 1) 30, citing Anonymous (Facebook Post, April 2019) (emphasis added). See also at 16,76 .

98 Megaphone for Hate (n 1) 30, citing Anonymous (Facebook Post, July 2019) (emphasis added). See also at 8, 16, 35, 37, 64.

99 See Megaphone for Hate (n 1).

100 ibid 7.

101 See ibid.

102 ibid 7-8.

103 See 'Community Standards', Facebook (Web Page) $<$ https://www.facebook.com/communitystandards/>.

104 ibid. 
new accounts each time and continue posting, ${ }^{105}$ which again calls into question Facebook's capacity to step up against online hate speech. Furthermore, Avaaz also came across certain similarities between the degrading language used to describe mostly Muslim minorities in the State of Assam and hateful comments targeted at the Rohingya in Myanmar. ${ }^{106}$ Also, Avaaz points out that what aggravates the problem is that regional and national media outlets amplify the dehumanising statements of high-ranking politicians, military and government officials by directly quoting their hateful remarks in the headlines of the media outlets' Facebook posts. ${ }^{107}$ In the report, Avaaz makes a number of recommendations to Facebook, ${ }^{108}$ the Indian Government, as well as to the United Nations and the international community (in addition to the points mentioned in the United Nations Strategy and Plan of Action on Hate Speech) to address the issue at hand. 109

In the subsequent sections the report demonstrates a number of concrete examples of hateful posts (including pictures, videos, discussions) spread on Facebook, also providing translations thereto which may serve as tangible evidence of hate speech. ${ }^{110}$ The report also flags an important connection between the two mentioned statelessness crises that are linked to hate speech, highlighting that the approximately 40,000 Rohingya Muslims having found refuge in India mostly in the State of Assam - are often referred to as 'Bangladeshi' by Hindunationalist social media users and have become subjected to hate speech on the mentioned social media platform. ${ }^{111}$ This reveals the heart-breaking reality that after suffering from the implications of hate speech in Myanmar, the Rohingyas fled their home country only to find another country where they continue to be subjected to further hateful comments, which may have similarly grave consequences as what they suffered in Myanmar.

\section{CONCLUSION}

In the twenty-first century, our globe consists of countries with emerging economies, high tech gadget arsenals and diverse societies where nationality is not

105 ibid 25.

106 ibid 29-34.

107 ibid 8, 21, 39-45.

108 Recommendations aimed at the United Nations and the international community at large include:

- Monitor and collect data on hate speech against minorities both on social media and in mainstream media, particularly against the backdrop of the threat of a citizenship exercise like the NRC.

- Support victims of hate speech in Assam, in particular those excluded from the NRC and ensure there is no escalation in violence against them.

- Engage state and non-state actors spreading hatred online and offline in India. Bring together stakeholders, including new and traditional media to ensure all stakeholders take responsibility to stop the spread of hate speech. Start with Assam as an important test case.

- Engage social media companies on how they can fulfil UN principles to protect vulnerable minorities and address hate speech in India and encourage partnerships between these companies to stop the misuse of their platforms by those spreading hate ibid 13. and disinformation.

109 See UN Strategy and Plan of Action on Hate Speech (n 5).

110 See, eg, Megaphone for Hate (n 1) 19-20.

111 ibid 29. 
a privilege shared by all. In order to maintain the status quo in their favour, some dominant groups have used nationality as a means of marginalising minority groups. This plain reality goes beyond the question of compliance with international human rights standards and instruments. In some countries discrimination, hate speech, related stigmas and false perceptions about minority groups are rooted so deeply in the majority society that it is difficult to shift the public discourses to the positive. This is especially the case in the context of social media, where it remains very difficult to moderate discussions in all languages and keep hateful comments and content under control. The problem is that the more hate speech remains unreported/unremoved on Facebook, the more minorities may become targets of violence on the ground. Furthermore, online and offline hate speech targeting ethnic/religious minorities are often conducive to systematic discrimination, exclusion and eventual denationalisation and vice versa; stateless minorities may easily become targets of hate speech in the absence of any state protection and popular representation.

Therefore, considering the very harmful long-term implications of hate speech both on the individual and societal level and based on the outcomes of Facebook's insufficient efforts to effectively address hate speech spread on its platform, the adoption of strong anti-hate speech laws - designed to protect the human rights of minorities criminalising hate speech in line with international human rights standards, including online hate speech — throughout the Asian continent must be part of any effective collective response to hate speech incidents, as well as the adoption of national action plans to address hate speech in partnership with civil society. This would require a coordinated regional approach that could tackle the root causes and drivers of hate speech, as well as its impact on victims and societies in a comprehensive manner. In a further attempt to prevent discrimination, hate speech and abuses against stateless minority groups and those who may be at high risk of statelessness, inter-group and inter-religious dialogue must be given priority at the very local, domestic and regional levels to be able to address the root causes and drivers of hate speech.

In these pursuits, regional actors - in the case of Myanmar, the Association of Southeast Asian Nations ('ASEAN') and in relation to India the Dialogue Mechanisms between India and ASEAN - who are politically motivated by their interest to maintain regional stability, could intervene as mediators reconciling the parties and influencing the nationalist agendas of the concerned states. If left unaddressed, hate speech, human rights violations and the escalation of violence may have further implications on regional stability. Therefore, in order to address the situations at hand, the governments of Myanmar and India should be put under international pressure to amend their nationality legislation in such a way to include the mentioned stateless minorities in the body of their citizens, allow facilitated naturalisation of those who were excluded from the list of citizens and prevent future cases of statelessness. To this end, developing effective forms of popular and legal representation for minorities will also be an important element in their empowerment. 